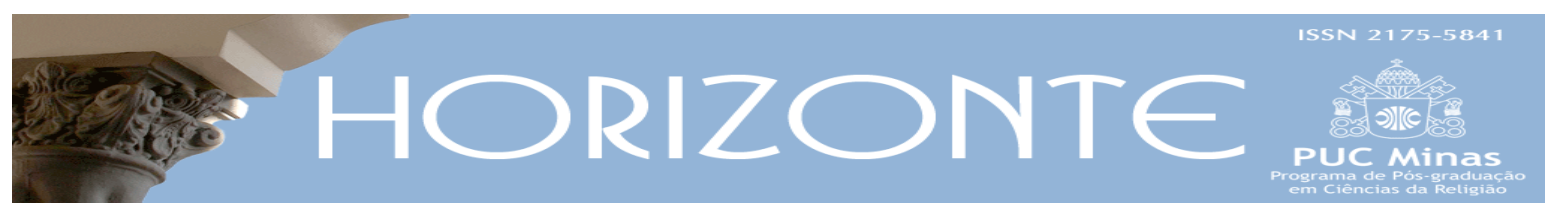

Dossiê: Fundamentalismos e Democracia - Temática Livre (9) $\odot$

\title{
A perspectiva das duas espécies de justiça em Lutero como resposta crítica às crises contemporâneas: uma opção do pensar teologicamente a justiça em tempos sombrios
}

\author{
The perspective of the two types of justice in Luther as a critical response to \\ contemporary crises: \\ an option of thinking theologically the justice in dark times
}

Carlos Flavio Teixeira*

\begin{abstract}
Resumo
Este artigo trata da perspectiva das duas espécies de justiça conforme esboçada por Martinho Lutero e evidencia sua pertinência como resposta crítica às crises contemporâneas. Para isso, retoma a leitura da exposição de Lutero em seu "Sermão Sobre as Duas Espécies de Justiça", relembrando os contextos histórico e bíblico de sua abordagem. A partir daí, aponta a crise de justiça como causa central das demais crises, reconhecendo suas possíveis motivações e consequências como condicionantes dos conflitos de justiça ainda vivenciados pela sociedade atualmente. Segue apresentando as noções de justiça exterior e justiça apropriada como resposta a esse caótico cenário e em protesto às formas insuficientes de justiça. Menciona os contornos e efeitos dessa proposta, notadamente seu potencial de interpelar a injustiça ao reascender na humanidade a chama da Justiça por meio da fé e da esperança. Conclui-se destacando a atualidade da perspectiva estudada e sua plausibilidade como opção para o pensar teologicamente a justiça em tempos sombrios.
\end{abstract}

Palavras-chave: Bíblia. Martinho Lutero. Justiça. Espécies. Desafios e perspectivas.

\begin{abstract}
Abstract: This paper deals with the perspective of the two kinds of justice as outlined by Martin Luther and highlights their pertinence as a critical response to contemporary crises. With this objective, the study resumes the reading of Luther's exposition in his "Sermon on the Two Species of Justice", recalling the historical and biblical contexts of his approach. From then on, it points to the justice crisis as the central cause of the other crises, recognizing its possible motivations and consequences as conditionings of the conflicts of justice still experienced by society today. It continues to present the notions of external justice and appropriate justice in response to this chaotic scenario and in protest of the insufficient forms of justice. It mentions the contours and effects of this proposal, notably its potential to heckle injustice by rekindling in humanity the flame of Justice through faith and hope. It concludes by highlighting the relevance of the studied perspective and its plausibility as an option for thinking theologically about justice in dark times.
\end{abstract}

Keywords: Bible. Martin Luther. Justice. Species. Challenges and perspectives.

Artigo submetido em 14 de maio de 2019 e aprovado em 15 de fevereiro de 2020.

* Doutor em Ciências da Religião pela UMESP. Docente e pesquisador no Seminário Adventista Latino-Americano de Teologia (SALT). País de origem: Brasil. E-mail: carlosflavioteixeira@gmail.com 


\section{Introdução}

O mundo vive atualmente perceptíveis e profundas crises das mais variadas, causadas por uma complexa combinação de fatores. Seu resultado é um quadro sombrio que desafia até mesmo as perspectivas mais otimistas. Essa caótica situação é percebida em equivalente medida no continente sul-americano e no Brasil. Este continente e país não escapam às causas e efeitos mais profundos do emblemático contexto conflituoso hoje notado entre as nações.

No âmbito político, os prolongados escândalos reveladores de corrupção veem acompanhados de seus efeitos na falência dos serviços públicos mais essenciais necessários à população. No âmbito jurídico, o estrangulamento do sistema judicial, causado pela judicialização da vida em sociedade, vem acompanhado de um lado pelo ativismo judicial que chama a atenção por sua intensificação e exacerbação nos últimos anos, e, contraditoriamente, de outro lado caracterizado pelas crescentes ameaças e mitigação aos direitos humanos.

No âmbito econômico, as mudanças bruscas nos mercados veem acompanhadas das instabilidades cada vez mais frequentes que assolam com mais efeitos as camadas pobres, intensificando o desemprego e aumentando o número dos que estão em piores condições de vida. No âmbito ecológico, o enfraquecimento na conscientização coletiva quanto à necessidade de cuidado da criação vem acompanhado do retrocesso nas ações governamentais de preservação das condições de vida no planeta.

No âmbito social, o aumento da miséria e exploração das fragilidades humanas vem acompanhado do vertiginoso aumento nos índices de violência em suas mais cruéis formas de incidência. No âmbito religioso, a efervescência no interesse pela prática religiosa vem contraditoriamente acompanhada do aumento da corrupção, por parte de alguns dirigentes e suas empresas religiosas, e do estilo de vida descomprometido com Deus e com o próximo, por parte da grande maioria dos religiosos. 
De fato, parece mais coerente falar em diversas crises, embora seja notório que todas elas se entrecruzam no cotidiano humano. Parece haver uma crise ética generalizada que está presente no ser humano constituinte de todo o tecido social onde se encontram a política, o sistema jurídico, a economia, a ecologia, a sociedade e a religião.

Nesse desafiador contexto, são muitas as propostas de análise crítica que emergem de todos os ramos das ciências, cada qual buscando dar sua contribuição para o mapeamento do problema e suas possíveis causas, algumas das quais arriscando-se a propor medidas que entendem ser solucionadoras para o problema.

O que ocorre, no entanto, é que devido às peculiaridades de seu paradigma epistemológico (científico), essas perspectivas se vêem limitadas quanto ao estudo das causas e soluções maiores ou mais profundas (metafísicas) que envolvem o problema. Daí a necessidade de um diálogo enriquecedor entre essas ciências, que podem contribuir positivamente no mapeamento dos efeitos da crise, e a teologia, que pode propor respostas em nível “ôntico" quanto às suas possíveis causas e atenuantes que estão além dos limites científicos (PROVINCIATTO; KIRCHNER; 2017).

Chamada à sua responsabilidade pública, a teologia protesta contra o desinteresse (e abandono) por Deus e por Sua Palavra e, consequentemente, pelo que é correto, apontando ser este o denominador comum que, em graus variados, caracteriza esses diversos âmbitos de crise. Nesse contexto, noções/parâmetros essenciais tais como a Verdade e sua justiça são ignoradas ou confundidas e os efeitos têm sido trágicos para os humanos e toda a criação. Por entender que a crise pode ser uma oportunidade de irruptura de Deus no contexto de seu abandono pela sociedade, tais crises desafiam a reflexão teológica.

Em um contexto de causas e efeitos semelhantes no período da Reforma, embora peculiarmente caracterizado, Martinho Lutero propôs um retorno à revelação divina e seu conceito de justiça como resposta às crises de seu tempo (SANTOS, 2010). A despeito das já reconhecidas "polaridades estruturantes da 
hermenêutica de Lutero" (RODRIGUES, 2016), "importa esclarecer que a Reforma - sobretudo a luterana - não é uma briga ultrapassada de teólogos de séculos passados, mas um movimento poimênico com motivações sérias, preocupado com o bom êxito do viver e morrer humanos" (BARTH, 2007, p. 134-135).

Embora essa proposta do Reformador deva ser vista no conjunto de sua obra, sua especificidade chama a atenção pela pertinência em face do cenário de crise de nossos dias. Mostra-se um interessante referencial para reflexão teológica da justiça no contexto em que vivemos. Como mencionou Sung (2016, p. 22), abrese um espaço para o "diálogo" com as ideias do Reformador que possam contribuir para "repensar o nosso presente e futuro", na busca de soluções necessárias aos "desafios de nosso tempo".

Dentre os muitos textos em que Lutero trata do tema da justiça, chama a atenção a abordagem esboçada no seu "Sermão Sobre as Duas Espécies de Justiça"1, cujo conteúdo será objeto de maior atenção neste breve estudo ${ }^{2}$. Sua abordagem começará relembrando os contextos (histórico e bíblico) do conteúdo proposto por Lutero. Em seguida destacará sua proposta de justiça delineada no conteúdo do seu texto. Ao final, concluirá evidenciando a pertinência da aplicação de tal proposta na desafiadora conjuntura de injustiça dos dias atuais.

\section{A exposição de Lutero e seu contexto}

O chamado Sermo de duplici iustitia, ou "Sermão Sobre as Duas Espécies de Justiça”, é uma exposição formulada e apresentada por Martinho Lutero possivelmente no final da páscoa de 1518 ou 1519, já que não se sabe ao certo o ano exato. O texto, de poucas páginas, mas de muita profundidade teológica, é um chamado à reflexão sobre a necessidade humana da justiça, ao mesmo tempo em que explica a existência de duas espécies de justiça e segue caracterizando-as e

\footnotetext{
${ }^{1}$ O conteúdo na íntegra pode ser lido em Lutero (2004, p. 241-248).

${ }^{2}$ Este estudo será auxiliado por outros conteúdos de Lutero, escritos posteriormente, e que estão relacionados ao tema da justiça, no intuito de se ter uma ideia mais ampla da perspectiva do reformador quanto ao tema. Os textos complementares ajudam a perceber que, em linhas gerais, o reformador manteve a mesma ideia elementar das duas espécies de justiça ao longo de sua carreira teológica e pastoral.
} 
tratando da relação entre ambas. Aponta ainda para os resultados de sua experiência na vida humana e termina propondo sua melhor aceitação e vivência.

Dois são os contextos mais influentes na argumentação de Lutero. O primeiro é o contexto histórico de seus dias, cenário no qual o Lutero monge reconhecia a situação caótica que motivava a necessidade de uma resposta pastoral por parte da igreja nesse seu papel eclesiástico. O segundo é o contexto bíblico, conteúdo no qual o Lutero professor de teologia via como a base para se buscar orientação para o papel pastoral a ser prestado pela igreja. Ao ler o contexto histórico de seus dias, a partir do contexto bíblico3, Lutero reconheceu que a patente necessidade de justiça que permeia toda a história do ser humano, em seu estado caído, estava entre as causas do caos religioso e social de seu tempo. Para ele, a revelação é clara em descortinar a realidade da ausência de justiça inerente ao ser humano e as crises perceptíveis de seus dias apenas evidenciavam isso de forma patente.

Lutero reconhecia que a falta de entendimento acerca da justiça, conforme revelada por Deus, agravava ainda mais a situação contingencial de injustiça característica ao ser humano. Havia um notório contraste entre o conhecimento de Deus e sua justiça, em Cristo, em relação à realidade do ser humano em sua injustiça inerente 4 . Com base nessas premissas, Lutero chama atenção para a necessidade humana de verdadeira justiça, apontando que apenas Deus, em Cristo e por meio do Espírito Santo poderia solucionar tal carência. Como resposta, o Evangelho da graça inclui a boa nova de que Deus perdoa o pecador que Nele crê. Mesmo em sua inerente injustiça humana, por meio de Sua graça e mediante a fé, Deus atribuiu ao pecador sua justiça divina (exterior) e passa a reproduzi-la também como agente transformador na vida do pecador perdoado (própria). Dessa

\footnotetext{
${ }^{3}$ Lutero (2003a, p. 280-281), em sua exposição sobre Romanos, menciona que, "na Escritura, interpretam-se os termos 'justiça' e 'injustiça' de um modo muito diferente daquele aceito pelos filósofos e juristas. Isso se manifesta pelo fato de eles afirmarem que [justiça e injustiça] são qualidades da alma, etc. A 'justiça' da Escritura, porém, depende mais da imputação de Deus do que da condição [do ser humano]. Pois não possui justiça aquele que apenas é dotado de alguma qualidade; antes, pelo contrário: esse é totalmente pecador e injusto. Só possui a justiça aquele que Deus 'misericordiosamente' considera justo por causa da confissão de sua própria injustiça e pelo fato de ele clamar pela justiça de Deus, e aquele que Deus quer que seja tido como justo junto a si. Portanto, todos nós nascemos e morremos em iniquidade, isto é, na injustiça; somos justos, porém, unicamente pela imputação de um Deus misericordioso através da fé em sua Palavra".

${ }^{4}$ Lutero (2003a, p. 322), em sua exposição sobre Romanos, menciona que, "um ser humano está no pecado como o terminus a quo [ponto de partida], e na justiça como o terminus ad quem [ponto de chegada]".
} 
forma, "a justiça teria uma dupla dimensão: a interna e a externa, a pessoal e a social. A justiça da fé e a justiça da política", dimensões essas que "vinculam-se de forma dialética" (GRAFF; PAULY, 2017, p. 350). É nessa perspectiva que Lutero desenvolve sua proposta das duas espécies de justiça como resposta às desafiadoras crises enfrentadas pelo ser humano.

\subsection{A justiça exterior}

Lutero reconhecia no ensino bíblico a noção de que o ser humano é inerentemente injusto e que há fartas evidências disso ( $\mathrm{Rm}$ 3:9-18), bem assim o fato de que apenas Deus é justo e a fonte de toda a verdadeira justiça (Gn 18:25; Ed 9:15; Sl 7:11, 11:7, 97:2; Is 45:8; Rm 3:26; 1Jo 1:9; Ap 16:5). Deus, lembra ele, "é a própria justiça, que nada ama mais do que a justiça” (LUTERO, 2004, p. 361). Conforme já notado, “o ponto de partida antropológico de Lutero e acima de tudo o conteúdo de sua antropologia possibilitaram-lhe especificar mais claramente os limites da ação humana - simultaneamente justa e pecaminosa - contra idolatria, injustiça, opressão e sacrifícios idolátricos na economia. Não resta a menor dúvida que Lutero, justamente na questão antropológica, pode trazer uma importante contribuição à reflexão teológica latino-americana” (RIETH, 1994, p. 83).

A partir de suas lentes antropológicas, Lutero inferiu que a verdadeira justiça não pode ser iniciativa ou produção humana. Ela só pode vir de fora do próprio ser humano, por isso é chamada de justiça exterior. Essa justiça é imputada ao ser humano e reproduzida nele e por meio dele, através do processo chamado de justificação (Rm 1:17, 3:21-28, 5:1-2, 8:1-4; Gl 2:16). A justificação inclui, portanto, a tríplice ação redentora de Deus em atribuir justiça (imputação) e reproduzir justiça no ser humano (regeneração) e por meio dele (testemunho). Na justificação, Deus não somente declara o pecador justo, mas também gradualmente o torna justo e assim o faz um agente de Sua justiça no mundo. Para além de justificar apenas o indivíduo, a redenção se projeta através do redimido em um movimento dinâmico que alcança e transforma também o mundo que este vive. Nessa perspectiva, a justificação é a redenção do ser humano "em" seu mundo. 
Para evidenciar esse ensino, Lutero recorda o conteúdo de três textos bíblicos. O primeiro quanto às palavras do salmista: “Em ti, Senhor, me refugio; não seja eu jamais envergonhado; livra-me por tua justiça” (Sl 31:1). Lutero lembra que “ele não diz 'por minha', mas 'por tua', isto é, pela justiça de Cristo, meu Deus, que foi feita nossa pela fé, pela graça, pela misericórdia de Deus” (LUTERO, 2004, p. 243). A justiça, portanto, é inerentemente divina e apenas apropriadamente humana. Daí se entende o amplo sentido do segundo texto, o qual evoca as palavras de Jesus: "Eu sou o caminho, e a verdade e a vida; ninguém vem ao Pai senão por mim" (Jo 14:6). Não há justiça à parte de Deus e sem a mediação de Seu Cristo. Somente por meio de Cristo a justiça divina se estende ao ser humano no mundo em que vive. Quanto a isso, o terceiro texto, agora de Paulo, lembra que "vós sois dele, em Cristo Jesus, o qual nos tornou, da parte de Deus, sabedoria, e justiça, e santificação, e redenção" (1Co 1:30). Essa, disse Lutero, "é a justiça mediante a qual Cristo é justo e justifica pela fé” (LUTERO, 2004, p. 242).

A partir da leitura desses textos Lutero chega à conclusão de que "a justiça dos cristãos é de duas espécies” e explica que "a primeira espécie é a justiça alheia e infundida de fora", enquanto "a segunda justiça é nossa e própria” (LUTERO, 2004, p. 242-243). Para Lutero, a justiça exterior (ou divina) é um tipo de justiça passiva, ou seja, é recebida pela fé em Cristo. O ser humano, por si mesmo, não pode produzir esse tipo de justiça. Em seu estado pecaminoso, não há nada no próprio ser humano que possa originar e desenvolver a justiça em qualquer medida. Desta forma, é não somente impróprio, mas também insano, a pessoa buscar qualquer fundamento de justiça em si mesma. Conforme já lembrado, ao argumentar desta forma radical, "a teologia de Lutero presta um serviço à competência existencial das pessoas por conhecer e incansavelmente apontar para a transcendência da existência” (BARTH, 2007, p. 135). O ser humano, portanto, não é um ser "em si” e “para si”. Antes, é um ser “de Deus”, chamado a viver "nele” e "segundo ele”, o que inclui sua amorável solidariedade.

Nota-se, nesse contexto, que a preocupação mais elementar de Lutero foi tentar identificar o que é a justiça. E ao invés de se demorar em argumentos 
buscando elaborar um conceito ou uma teoria, ele define justiça de forma mais prática. Justiça é primeiramente uma pessoa, Cristo, a face reconhecível de Deus aos humanos. E, secundariamente, justiça é a sua obra redentora no ser humano. Sendo Deus a verdadeira justiça e sua única fonte, e sendo Cristo o meio de acesso à tal fonte, somente através dele ela pode ser encontrada. Com isso Lutero quer apontar que a justiça não é somente um conceito, uma condição, uma situação, ou um modo de agir. Tudo isso tem seu importante lugar, mas há um fundamento, uma razão de ser que antecede e dá sentido a qualquer manifestação de justiça. Essa é a justiça de Deus em Cristo.

Quanto a seu primeiro efeito, "essa é a justiça infinita e que absorve todos os pecados num instante" (LUTERO, 2004, p. 243). Outro efeito é que, "pela fé em Cristo, portanto, a justiça de Cristo se torna nossa justiça, e tudo o que é dele passa a ser nosso" (LUTERO, 2004, p. 242), o que inclui a própria justiça. Isso por que, "quem crê em Cristo está apegado a ele e é uma coisa só com Cristo, compartilhando com ele a mesma justiça" (LUTERO, 2004, p. 243).5 Sua vida, então, passa a ser vivenciada como um justo, conquanto sua contingência existencial seja ainda a de um pecador, muito embora seja continuamente justificado pela fé.

Em resumo, o primeiro tipo de justiça, a chamada justiça alheia ou divina é aquela que: (1) vem de fora, por isso não é inerente aos humanos; (2) vem de Cristo, Aquele que é justo e por isso é a fonte da própria justiça. Esse tipo de justiça, quando aceito, produz outro tipo de justiça, a chamada justiça própria ou humana.

\subsection{A justiça própria}

Embora apenas Deus, incluindo-se aí Jesus Cristo, seja inerentemente justo (At 3:14, 7:52, 22:14; 1Jo 2:1,29), seres humanos são chamados justos ao receberem

\footnotetext{
${ }^{5}$ Também na obra Lutero (2000, p. 46), o reformador menciona que é "Jesus Cristo que ressurge da morte, condena o pecado e a morte, compartilha-nos sua justiça, dá-nos seus méritos, põe sua mão sobre nós, e [por isso] vamos bem, cumprimos a lei e superamos o pecado e a morte. Por isso a honra, o louvor e a ação de graças sejam dadas a Deus pelos séculos dos séculos, amém".
} 
e vivenciarem a justiça divina, como no caso de Abraão (Gn 15:6), José (Mt 1:19), João Batista (Mt 21:32), José de Arimatéia (Lc 23:50), Cornélio (At 10:22) etc. Foram chamados justos porque buscaram o reino de Deus e sua justiça (Mt 6:33) e os praticaram (Mt 25:37). Portanto, aquele que, pela fé, recebe a justiça e é transformado por ela, passando a praticá-la, esse é de fato justo (1Jo 3:7).

Para destacar este tipo de justiça, Lutero lembra as palavras de Paulo ao ensinar "que a justiça de Deus se revela no evangelho, de fé em fé, como está escrito: o justo viverá pela fé” (Rm 1:17). O Reformador pontua que "essa justiça é a primeira, é o fundamento, a causa, a origem de toda a justiça própria e atual. Porque de fato a mesma é concedida em lugar da justiça original, perdida em Adão" (LUTERO, 2004, p. 243). É concedida a “nós, seres indignos, por pura misericórdia, ainda que, na verdade, teríamos merecido ira e condenação” (LUTERO, 2004, p. 242). O ser humano, portanto, somente pode vivenciar a verdadeira justiça em termos de reprodução da justiça divina em seu viver.

Lutero lembra que a "justiça original” (LUTERO, 2004, p. 243), aquela que existia no ser humano antes da queda, foi perdida quando o ser humano optou por outro fundamento de justiça. Tal opção alterou os valores, princípios e as regras de justiça até então vivenciados. Amor, fraternidade e solidariedade foram impactados por egoísmo, insensibilidade e indiferença. $\mathrm{O}$ resultado disso pode ser notado na persistente crise de justiça que os humanos vêm experimentando ao longo de sua história. À luz de qualquer outro paradigma de justiça, o ser humano não pode e não consegue, mesmo com o melhor de seus esforços, ser justo.

Por isso Lutero propõe o que ele chamou de justiça própria ou também chamada de nossa justiça. Essa justiça é em parte passiva e em parte ativa6 ${ }^{6}$ É passiva porque é recebida pela fé. Conforme proposto, é "essa justiça alheia, portanto - infundida em nós sem atos nossos, somente pela graça, ou seja, quando o Pai nos leva interiormente a Cristo” (LUTERO, 2004, p. 243). E é ativa porque,

\footnotetext{
${ }^{6}$ Lutero (2008, p. 30-35) mais tarde criticaria a "justiça ativa" que se baseia unicamente na pretensão de justiça humana por meio da prática de obras. Entretanto, tal crítica não alcança a justiça que é em parte ativa como desdobramento da justiça passiva, antes recebida pela graça.
} 
embora seja recebida passivamente, ela é apropriada cooperativamente. Assim, essa justiça é nossa, "não porque nós a operamos sozinhos, mas porque cooperamos com aquela primeira e alheia” (LUTERO, 2004, p. 243).

Ao ser desta forma apropriada, essa justiça produz resultados "no" ser humano e "por meio do" ser humano. Ela opera no ser humano regenerando-o progressiva e continuamente. Isso porque "a justiça alheia não é infundida toda de uma vez, mas começa e progride e é levada finalmente à perfeição com a morte" (LUTERO, 2004, p. 243). Tal justiça, que também foi chamada de interior, embora "nunca seja alcançada completamente nesta vida, sempre se deve buscá-la" (LUTERO, 2003b, p. 522). E na medida em que vai sendo apropriada, ela regenera o ser humano direcionando sua vontade e seus esforços para uma vida de obediência às leis de Deus. Contudo, "essa segunda justiça é obra da justiça anterior, fruto e consequência da mesma, conf. Gl 5:22" (LUTERO, 2004, p. 243).

Depois de apresentar esses contornos da justiça própria, Lutero caminha para o final da sua exposição e não a termina sem antes apresentar a Cristo também como o exemplo do viver justo. Ou seja, além de Cristo ser a fonte da justiça e seu agente regenerador, Cristo é também seu exemplo de prática. Para destacar isso, Lutero menciona o texto de Paulo aos filipenses: "Tende em vós o mesmo sentimento que houve também em Cristo Jesus, pois ele, subsistindo em forma de Deus, não julgou como usurpação o ser igual a Deus; antes, a si mesmo de esvaziou, assumindo a forma de servo, tornando-se em semelhança de homens; e, reconhecido em figura humana, a si mesmo se humilhou, tornando-se obediente até a morte e morte de cruz" (Fl 2:5-8).

Lutero destacou, desse texto paulino, o exemplo de Cristo em disposição e atitude abnegadas, o que ficou evidente em sua humildade constante, dependência de Deus e serviço solícito aos semelhantes. Para Lutero, essa é a forma como a justiça foi apresentada em termos práticos aos humanos. Nesse sentido, ele lembra que Cristo 
esvaziou a si mesmo, não querendo utilizar aqueles títulos frente a nós, não querendo ser diferente de nós; sim, antes tornou-se como um de nós e aceitou a forma de servo (isto é, sujeitou-se a todos os males). Mesmo sendo livre, como também diz o apóstolo, se fez servo de todos, não agindo de outra forma senão como se fossem seus todos esses males que eram nossos. Por isso ele tomou sobre si nossos pecados e castigos e agiu de forma a vencê-los como que para si mesmo, sendo que na realidade os venceu para nós. Com respeito a nós, ele poderia ser nosso Deus e Senhor. Ainda assim não o quis, mas preferiu tornar-se nosso servo. (LUTERO, 2004, p. 245).

Portanto, no exemplo de Cristo se nota que a justiça frutifica nas dimensões pessoal e relacional. Ela resulta, segundo Lutero, "na boa prática de boas obras: em primeiro lugar na mortificação da carne e na crucificação das concupiscências em relação a si mesmo, conf. Gl 5:24" (LUTERO, 2004, p. 243). Destaca-se um interessante detalhe dessa tônica luterana. São mencionadas a "boa prática" e as "boas obras", numa clara sugestão da inseparável relação entre os meios e os fins na prática da justiça. A justiça divina direciona apropriadamente "o que fazer" (boas obras) e "como fazer" (boa prática). Nessa perspectiva, não há lugar para as ideologias corrosivas da verdade, da justiça e da ética, como por exemplo a ideia de que "os fins justificam os meios".

O primeiro fruto, portanto, é a mortificação do eu, reconhecidamente egoísta e corrupto. "Em segundo lugar também no amor ao próximo; em terceiro, também na humildade e no temor a Deus, do que está repleto o apóstolo e toda a Escritura” (LUTERO, 2004, p. 243). O justo, então, é reconhecido em sua prática de justiça no âmbito de suas relações com Deus e sua criação, incluindo os demais seres humanos7. Conforme bem lembra Lutero, Paulo "resume tudo em Tito 2:12 dizendo: 'Sobriamente' (isto é, em relação a si mesmo, pela crucificação da carne), 'justamente' (em relação ao próximo), 'e piedosamente' (em relação a Deus) 'vivamos neste século" (LUTERO, 2004, p. 243). Essa é a ética da justiça divina apropriada como justiça própria. Nesse sentido, "a teologia reformatória de Lutero propõe rompimento da lógica em que o ser humano se concebe como autoreferente, auto-fechado, egocêntrico. Pela fé-confiança, o ser humano é tornado

\footnotetext{
${ }^{7}$ Lutero (2010b, p. 489) propõe que "quem não pratica a justiça para com o próximo não é um cristão verdadeiro, mas um cristão falso. Deus não quer cristãos que não pratiquem a justiça. Deus ama a justiça; portanto, os que são de Deus praticam a justiça".
} 
justo e vocacionado para a cooperação com a justiça de Deus, em favor da produção e reprodução da vida, através dos três âmbitos da vida: Igreja, economia e política” (WACHHOLZ, 2018, p. 213).

Em resumo, o segundo tipo de justiça, a chamada justiça própria ou humana é aquela que: (1) quando infundida, justifica pela fé o pecador que a aceita; (2) torna o pecador justo em Cristo na medida em que o regenera em justiça; e (3) condiciona-o a produzir frutos de justiça. Em razão de sua fonte, sua forma de realização e seus efeitos, esse tipo de justiça se afigura como uma proposta contemporânea de justiça dado sua pertinência e necessidade.

\section{Uma proposta contemporânea de justiça}

A exposição de Lutero, quanto às duas espécies de justiça, contribui positivamente para uma reflexão contemporânea acerca do tema, na medida em que sua perspectiva se mostra sensível ao notório conflito ainda existente quanto ao sentido de justiça, aos inevitáveis dilemas de justiça que as pessoas enfrentam, e à urgente necessidade de frutos genuínos de justiça nas dimensões pessoal e comunitária da vida humana.

Como pressuposto inicial de sua tratativa, Lutero reconhece a existência de uma crise generalizada de justiça. Essa crise é motivada, dentre outras causas, por um conflito quanto ao próprio sentido de justiça ${ }^{8}$, já que o ser humano confunde sua justiça caída com a genuína justiça. Como resposta, Lutero anuncia a justiça divina como a única verdadeira e denuncia como falsas as pretensas formas de justiça que nada mais são do que meras alternativas humanas, subterfúgios ou válvulas de escape ao que, de fato, é justiça em seu sentido mais profundo. Entender isso requer uma mudança de mentalidade que, na prática, produza

\footnotetext{
${ }^{8}$ Lutero (2010a, p. 367) propõe uma reflexão acerca da diferença entre a justiça como mera conformação às leis e regulamentos humanos (secular) e aquela que é a justiça centrada em Cristo (divina). Embora a primeira tenha sua validade quando praticada conforme a ordenação divina, ela ainda é limitada e por isso deve-se ter em mente que "a justiça que é válida diante de Deus centra-se tão somente em Cristo".
} 
empatia pela justiça (LUTERO, 2005a, p. 110). Desse ponto de vista, "nas questões práticas da vida, da administração do direito e da justiça, Lutero só vê duas possibilidades concretas: o bom senso e o amor. Mesmo nas questões públicas mais complicadas, estas duas regras poderão ser muito úteis, além de evitar que maiores injustiças destruam a vida e a dignidade humana” (ZWETSCH, 2016, p. 14).

Portanto, apenas a justiça em seu sentido mais profundo se mantém o paradigma dignificador da existência. Esta é a justiça que precisa ser desejada, aceita e vivenciada entre os humanos. Entendendo esta justiça como oposta àquela que é meramente humana, Lutero destaca comparativamente os antecedentes e as consequências de ambas. $O$ antecedente da justiça divina é a justiça original (também de origem divina) que existia em Adão antes da queda, enquanto o antecedente da justiça meramente humana é a justiça original em sua forma posterior à queda. Portanto, enquanto a justiça divina atual é a justiça concedida em lugar da original que era perfeita, a justiça meramente humana é a versão atual da justiça caída, corrompida desde a queda, e que se conforma à injustiça nas suas mais variadas formas.

Segundo Lutero, ao exercer sua liberdade, o ser humano inevitavelmente opta por um desses tipos justiça. E a essa manifestação ele chamou de "justiça atual”. A justiça atual é a vivência, no presente, de um dos dois tipos de justiça antecedentes. Essa justiça atual pode ser positiva ou negativa. Positiva, quando for a vivência atual da justiça exterior ou divina. É o tipo de justiça própria que se apropriou da justiça divina. Negativa, quando for a vivência contemporânea da justiça humana caída9. Esta última é um tipo de justiça própria que nega a apropriar-se da justiça divina.

\footnotetext{
${ }^{9}$ Lutero (2004, p. 246) menciona como exemplo Simão o leproso, conforme Lc 7:36.
} 


\section{Esquema 1 - Formas da justiça}
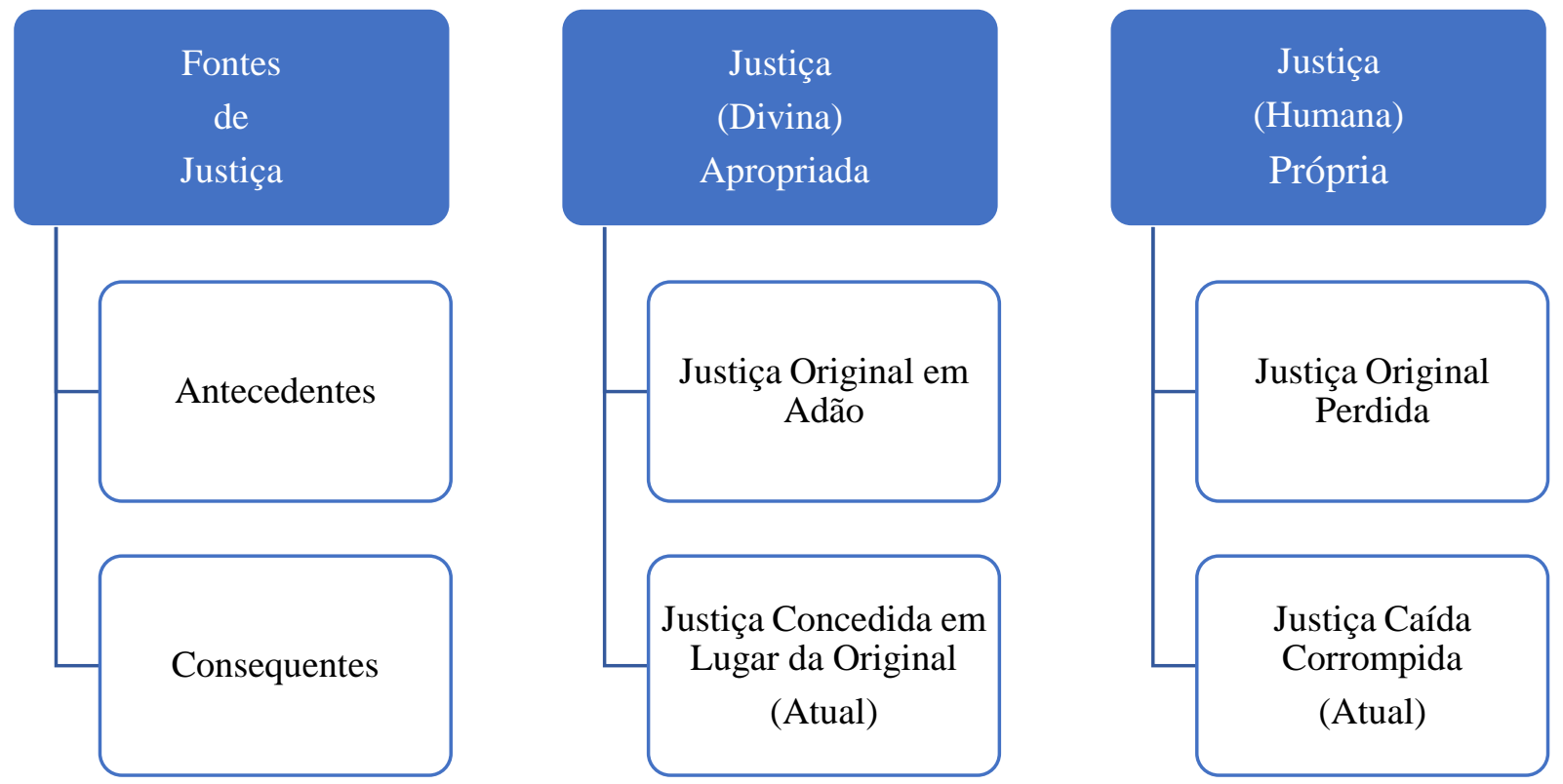

Fonte: Elaborado pelo autor.

Portanto, de acordo com Lutero existem sempre dois tipos de justiça em disputa pela supremacia, embora a justiça divina seja a única solução para a crise humana de justiça. A justiça divina é dada em Cristo, por meio da graça e que, uma vez apropriada pela fé, se torna a justiça de Deus nos seres humanos e passa a operar por meio deles. Tal justiça é concedida em lugar daquela originalmente existente em Adão e que foi perdida por ocasião da queda, como uma forma de restauração daquela e em detrimento da justiça corrupta meramente humana. “Essa justiça é contraposta ao nosso pecado próprio e atual” (LUTERO, 2004, p. 244). Ela confronta a outra justiça que é meramente humana, própria (embora não apropriada), que é inerente ao ser humano caído, um tipo de justiça corrompida que restou aos humanos após a perda da justiça original.

Devido ao potencial da justiça divina operar no ser humano frutos de justiça, Lutero a chama positivamente de "justiça atual” (LUTERO, 2004, p. 243). A justiça atual (em seu sentido positivo) é a justiça divina que foi imputada, pela fé, no ser 
humano que passou a ser justo "em" Cristo, produzindo frutos de justiça em sua vivência cotidiana. Quando se aceita a Deus como sua justiça, essa justiça é imputada "ao" ser humano e seu poder age "no" ser humano, desdobrando-se em justiça "por meio do" ser humano. Portanto, em Lutero, "as implicações éticas das relações Deus-pessoa e pessoa-pessoa precisam considerar os três estamentos (Stände), como máscaras (larvae) através das quais e pelas quais Deus atua. Lutero assume o princípio medieval, segundo a qual a humanidade foi ordenada por Deus em três estamentos, a saber, a Igreja (ecclesia), o lar/domicílio (oeconomia) e o Estado (politia)"; (WACHHOLZ, 2016, p. 1200). Desta forma, a justiça divina é vivenciada como justiça comunal na medida em que se mostra a presença atualizadora da genuína justiça nos âmbitos comunitários (família, igreja, sociedade).

\section{Gráfico 2 - A justiça divina vivenciada como justiça comunal}
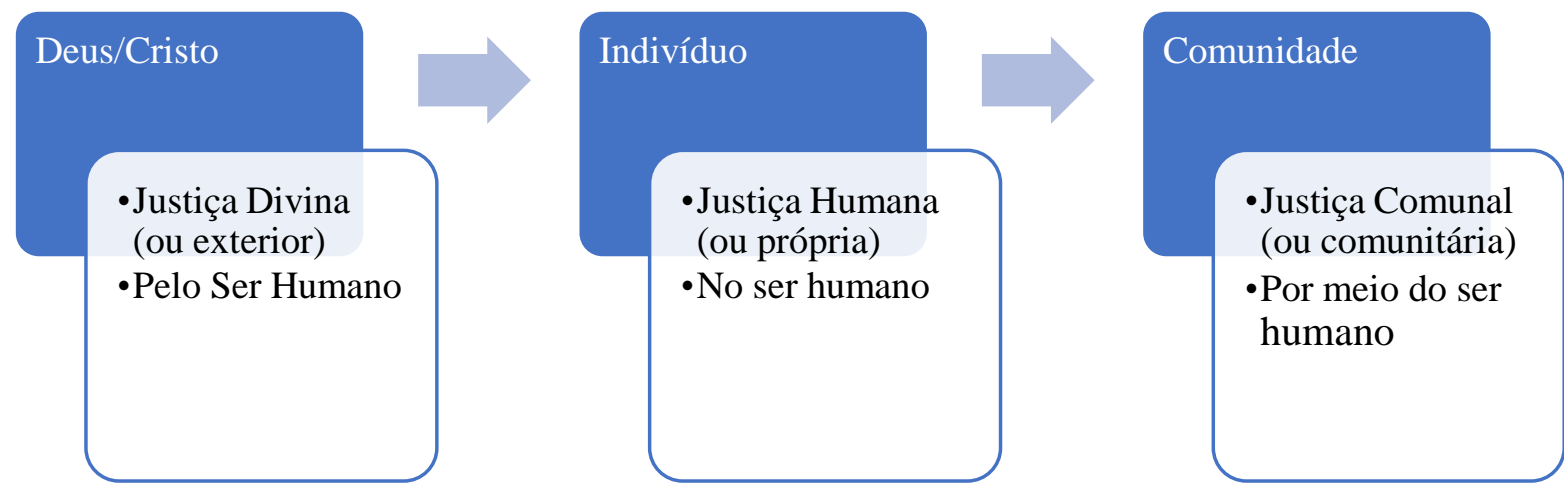

Fonte: Elaborado pelo autor.

Conforme ilustra o gráfico acima, a Justiça divina (ou exterior), que é centralizada em Cristo, é a justiça em favor do ser humano. Quando aceita e apropriada, essa justiça produz a justiça humana (ou própria), que é a justiça divina no ser humano. Essa justiça, por sua vez, produz a justiça comunal (ou comunitária), que é a justiça divina sendo realizada em nível coletivo por meio dos seres humanos. Para Lutero é impossível, portanto, que haja justiça à parte de 
Cristo. Toda justiça em nível comunitário somente pode ter origem na justiça de Deus pelo ser humano e ser mediada pela justiça de Deus na pessoa ${ }^{10}$. Separado de Cristo, a justiça própria do ser humano não passa de tentativas mal sucedidas que resultam em arrogância pessoal e fracasso coletivo. Por outro lado, a justiça divina é ativa em sua vocação de se solidarizar e servir ao próximo. Sua apropriação no ser humano o vocaciona a se relacionar de forma justa com a criação e os demais seres humanos em todos os níveis comunitários.

Além ser pertinente por apresentar o sentido genuíno de justiça e denunciar a falsidade das formas de justiça alternativas, a abordagem de Lutero é contemporânea na medida em que ele trata dos dilemas elementares de justiça que os seres humanos de todas as épocas enfrentam. Partindo da premissa de que todos têm, ao mesmo tempo, a necessidade de justiça e a obrigação de promover e defender a justiça, ele deixa implícito o princípio da proporcionalidade, pelo qual todo indivíduo é responsável pela justiça na medida das oportunidades e prerrogativas recebidas de Deus. Por isso, "é esperado de pastores e teólogos o pregar e profetizar em promoção da justiça, ordem, e o bem comum” (WITTE JR, 2017, p. 6). Nesse contexto, Lutero reconhece as diferentes responsabilidades das pessoas públicas e privadas quanto à realização da justiça.

Às pessoas públicas, entendidas como "as que estão a serviço de Deus ou ocupam posição de direção" espera-se atenção e cuidado proporcional a seu âmbito de poder e influência, já que "a essas cabe, por dever do cargo e por necessidade, punir e julgar maus, vingar e defender os oprimidos" (LUTERO, 2004, p. 247). Entretanto, em razão de suas posições, essas pessoas jamais podem valer-se de suas prerrogativas para postular justiça em favor de si mesmas. Suas prerrogativas de justiça devem ser exercidas "com referência aos assuntos dos outros, não dos próprios" (LUTERO, 2004, p. 247). Não deve jamais exercê-las em seu próprio interesse. Se tiverem alguma causa própria devem socorrer-se da justiça por meio

\footnotetext{
${ }^{10}$ Lutero (2007b, p. 211) menciona que a justiça divina opera interna e externamente. Ele diz: "Portanto, devemos ser justos diante de Deus e dos seres humanos, do que isso é o testemunho. [...] A justificação espiritual é dupla. Onde a justificação ocorre entre Deus e o ser humano, ela acontece a partir da causa eficiente da justificação. A outra é corporal e externa, a que se dá entre ser humano e ser humano; esta acontece a partir do efeito da justificação".
} 
de outros de seus representantes. Vale lembrar que, ao mencionar o texto de Rm 13 para falar de pessoas públicas, Lutero está estendendo às autoridades seculares o mesmo princípio de responsabilidade pela justiça aplicável às autoridades religiosas.

Já quanto às pessoas privadas, entendidas como aquelas que estão agindo em "causa própria”, e não no interesse coletivo, Lutero menciona três tipos dessas pessoas com suas respectivas posturas distintas quanto à busca da justiça.

O primeiro tipo, maior grupo dentre todos, diz ele, são as justiceiras, aquelas que buscam justiça retributiva. São aquelas que confundem justiça com vingança e por isso "são as que querem vingança e procuram julgamento junto aos representantes de Deus" (LUTERO, 2004, p. 247). Seu discurso é de busca pela justiça, mas sua intenção e práticas têm sede de retribuição e vingança. Essas pessoas querem a reparação de algum dano e o castigo do ofensor. Para o Reformador, esse tipo de atitude às vezes é tolerado para evitar que essas pessoas vinguem a si mesmas por meio de violência ou busquem, por sua própria conta, reparação de danos sofridos. Mas adverte que essa postura é reprovável e precisa ser extinta, já que nada mais é do que "procurar a vantagem própria” (LUTERO, 2004, p. 247) e isso evidencia que o sujeito não foi transformado pela justiça divina.

O segundo tipo de pessoa são as apropriadamente justas. Elas "não resistem a maldade alguma" por meio de violência, quando sofrem injustiça "não procuram vingança” e estão dispostas a sofrer maior perda a fim de não comprometer a realização da justiça divina. Essas pessoas não buscam meramente a reparação do dano e tampouco o castigo do seu ofensor. Elas andam a segunda milha. Estão antes preocupadas com levar pessoas injustas à verdadeira Justiça do que usufruírem a si mesmas do que é humanamente justo. Lutero menciona que: 
Essas pessoas lamentam mais o pecado dos que as ofendem do que o próprio dano e a ofensa. E preferem agir de modo a chamar aqueles de volta do pecado do que vingar as injúrias de que são vítimas. Por esta razão, despem-se das formas de sua justiça e vestem as formas daqueles, orando pelos que as perseguem, falando bem dos que falam mal, fazendo o bem aos que lhes fazem mal, prontas a sofrer e satisfazer as penas em favor dos seus próprios inimigos, para que sejam salvos. Esse é o Evangelho e exemplo de Cristo. (LUTERO, 2004, p. 248).

É no mínimo intrigante, portanto, que à luz do Evangelho, o justo seja aquele que, abrindo mão da justiça meramente humana que lhe pertence por direito contingencial e que usualmente pleiteia em seu próprio favor, presenteia o injusto com os raios da justiça divina - na forma de amor e perdão - que brilham por intermédio de seu testemunho. Como na época de Lutero, ainda hoje este tipo de justiça está em falta, embora seja urgente e necessário para curar as feridas de nossa sociedade em convulsão pela sua ausência. Entretanto, nem de longe isso significa abrir mão da justiça em si, pois o contraste aqui feito não é entre o querer ou não a justiça, mas quanto a que tipo de justiça se busca, a profunda justiça do paradigma divino ou a precária justiça do paradigma humano.

O terceiro tipo de pessoa mencionado por Lutero são as justificáveis, ou seja, aquelas que pretendem justificar como plausível seu clamor por justiça disciplinar. Essas pessoas não buscam a reparação do dano sofrido, mas exigem o imediato castigo do ofensor. Alegam que a punição é necessária para corrigir a injustiça sofrida e o próprio injusto, a quem, "segundo vêem, não pode ser emendado sem punição" (LUTERO, 2004, p. 248). Segundo Lutero, o maior perigo, nesse caso, é "tomar a fúria por zelo e venha a ser convencido de que aquilo que crê fazer por amor à justiça foi, antes, feito por ira e impaciência. Porque a ira muito se assemelha ao zelo, e a impaciência ao amor da justiça” (LUTERO, 2004, p. 248).

Para o reformador, a justiça de Cristo motiva as pessoas justas e confronta as justiceiras e as justificáveis. Por meio de sua justiça, Cristo corrige a perversão humana, a qual inclui o pensamento egoísta, o sentimento de raiva e o exercício opressor do poder. $\mathrm{O}$ alcance dessa correção é de tal profundidade que abarca o ser 
humano como um todo e seus efeitos são vistos até mesmo nas atitudes do justo para com aqueles que são reconhecidamente injustos:

Assim ele fará com todos nós sempre que nos inflarmos por causa da nossa justiça, sabedoria ou poder e nos irritarmos com pessoas injustas, tolas e menos poderosas do que nós; pois então (esta é a maior perversão) a justiça opera contra a justiça, a sabedoria contra a sabedoria, o poder contra o poder. Pois tu és poderoso não para fazer os fracos ainda mais fracos, pela opressão, mas torná-los fortes, exaltando-os e defendendo-os. E és sábio para não rir dos tolos e, assim fazê-los ainda mais tolos, mas para acolhê-los, como queres que façam contigo, e para instrui-los. Assim, és justo para justificar e desculpar o injusto, não para condená-lo apenas, falar mal dele, julgá-lo e castigá-lo. Pois este é o exemplo de Cristo para nós. [...] Porém a natureza resiste violentamente, porque muito se deleita com a vingança e a glória de sua justiça e com a vergonha da injustiça de seu próximo. Por isso promove apenas sua própria causa e se alegra por estar melhor que a do próximo, acossando, contudo, a causa do próximo e desejando que ela vá mal. Essa perversão é toda a injustiça, contrária ao amor, que não procura o que é seu, mas o que é do outro. Deve-se, pois, lamentar que a causa do próximo não esteja melhor que a própria, e desejar que ela vá melhor que a própria, em que a alegria seja menor que sobre a própria causa; pois esta é a lei e os profetas. (LUTERO, 2004, p. 246-247).

Ao curar a injustiça humana, com sua corrupção e perversão, a justiça de Cristo produz frutos por meio da pessoa justa (LUTERO, 2007a, p. 165-166). Como isso ocorre na prática? Primeiro, sendo justo com os outros; segundo, suportando a injustiça por amor aos outros; e, terceiro, se opondo a toda e qualquer injustiça que afeta aos outros. Eis aí o que Lutero chamou de justo ou "homem de bem", que "é aquele que sempre insiste e se empenha com todas as forças para que tudo corra corretamente e todas as pessoas procedam com honestidade, e que ajuda a preservar e promover isso com palavras e ações, com conselhos e exemplos" (LUTERO, 2005a, p. 43). Ao ter suas lentes moduladas pela justiça divina, a vivencia de tal pessoa se faz um instrumento de tal justiça na vida de outros, reconhecendo-os em sua dignidade humana.

Tal pessoa aprendeu a amar e tal amor faz com "que cada cristão se torne servo do outro, a exemplo de Cristo" (LUTERO, 2004, p. 245). Isso é serviço. Dessa forma, "nenhum membro do corpo serve a si mesmo nem procura o que é seu, mas o que é do outro, e isso tanto mais, quanto mais fraco, doente e desonrado for 
aquele" (LUTERO, 2004, p. 246). Isso é sensibilidade e abnegação. A justiça que agora é sua, em Cristo, faz com que "aja com seu próximo como se fosse sua própria a fraqueza, o pecado e a ignorância do próximo; não se glorie, nem se ufane, nem desdenhe, nem triunfe contra aquele” (LUTERO, 2004, p. 245). Isso é solidariedade.

Esse tipo de amor justo tem impacto proativo em todos os seus âmbitos de convívio. "Então a alma não procura mais ser justa para si mesma, mas tem como sua justiça a Cristo; por conseguinte, ela procura apenas o bem dos outros" (LUTERO, 2004, p. 244), mesmo sabendo que isso lhe trará algum custo. Há, inclusive, disposição e resiliência em sofrer a injustiça, se necessário for, para que outros sejam de alguma forma alcançados pela Justiça ${ }^{11}$.

Mas, claro, além de mostrar justiça em seu trato e suportar a injustiça em seu desfavor, o justo também se opõe inegociavelmente à injustiça. Daí que, para Lutero, "temos que nos opor em primeiro lugar a toda a injustiça, onde a verdade ou a justiça estão sofrendo violência e passando por dificuldade. E nisto não devemos fazer qualquer distinção entre pessoas, como é o caso de alguns que lutam mui zelosa e ativamente contra a injustiça infligida aos ricos, aos poderosos e aos amigos; porém onde o pobre, o desprezado ou inimigo a sofre, eles ficam muito quietos e pacientes" (LUTERO, 2000, p. 123). A justiça, portanto, não pode ser seletiva. Não pode privilegiar uns em detrimento de outros, muito embora, para ser justa, deva ser sensível às necessidades peculiares "daqueles que estão sofrendo violência e passando por dificuldades".

Esta dimensão prática e solidária da justiça é outro ponto destacável da abordagem de Lutero que a faz contemporânea, na medida em se posiciona frente à urgente necessidade de frutos genuínos de justiça nas dimensões pessoal e comunitária da vida humana, em todos os seus níveis. É um convite relevante e atual para que as pessoas tenham "fome e sede de justiça”, que "jamais desistam

\footnotetext{
${ }^{11}$ Lutero (2005a, p. 56) lembra que, "se te é feita alguma injustiça ou violência, não tens o direito de consultar tua cabeça louca e começar imediatamente a vingar-te e a rebater. Antes, deves pensar no assunto e ver como tolerá-lo e como estabelecer a paz. Se isso, porém, não for possível e não consegues suportá-lo, tens a justiça e as autoridades no país, das quais podes exigir que se faça justiça. Pois elas foram instituídas para impedir essas coisas e castigar".
} 
nem cessem, e que jamais possam ser saciadas, que não procurem nem intentem outra coisa senão as exigências e a manutenção da justiça, e que, por outro lado, desprezem tudo que as impedir nisso" (LUTERO, 2005a, p. 44).

Em resumo, a reflexão luterana acerca das duas espécies de justiça se mostra pertinente no contexto contemporâneo porque: (1) nos ajuda a perceber os tipos de justiça em conflito e a discernir a genuína forma de justiça; (2) desmascara as formas enganosas de justiça usualmente disfarçadas na sutileza de pessoas “justiceiras" e "justificáveis"; e (3) interpela de maneira geral a todos os seres humanos e de maneira especial aos cristãos a serem pessoas justas, produzindo frutos de justiça nos âmbitos pessoal e comunitário de sua existência.

No âmbito da "dialética do possível” (SUNG, 2016, p. 38) - assim chamado o caminho factível que busca superar a realidade degradante sem cair nas armadilhas do idealismo utópico-, os efeitos de uma tal justiça se mostram na construção de uma ética cidadã (WACHHOLZ, 2018), por sua vez incidente na economia (RIETH, 1993; RIETH 1994), política (ROSA, 2016), educação (BARBOSA, 2011), sistema jurídico (WITTE JR., 2017), relações de trabalho (PAULY, 2000; EATON, 2013), meio ambiente (WESTHELLE, 1994), justiça social (ZWETSCH, 2016), etc.

\section{Considerações finais}

Embora haja quem seja indiferente ou até mesmo quem negue o contexto de crises em que vive o mundo e o Brasil, seus efeitos desafiam até mesmo as pessoas mais céticas. É inegável a existência de um complexo quadro de crises que afeta os valores, os princípios e as regras de vivência no âmbito dos povos e entre eles. Seus efeitos podem ser notados em todos os âmbitos da vida, sendo perceptíveis também na política, direito, economia, ecologia, sociedade, religião etc. Na base desse caos está a crise de justiça. E nesse contexto é paradoxal que, ao mesmo tempo em que clama por justiça, a sociedade sequer tenha um consenso quanto ao que seja justiça, além de já não mais aceitar um sentido convergente de justiça. 
Entretanto, no caminho de superação desse caos, o ponto de partida parece ser uma reflexão acerca da própria justiça. Afinal, o que é justiça? Estamos em busca do quê quando clamamos por justiça? O conflito fica evidente já em nosso ponto de partida quando somos interpelados pela indefinição na questão elementar do sentido de justiça. Por mais desafiador que seja, esse parece ser o ponto por onde se recomeçar. Sua retomada é não somente útil, mas necessária. Afinal, como se falar em justiça na política, direito, economia, ecologia, sociedade, religião etc., enquanto não se tem claro em mente que justiça é essa que se está buscando?

A teologia tem muito a contribuir para essa reflexão, pois em seu caráter meta científico ela pode transpor os limites das demais ciências do conhecimento e descortinar sentidos que lhes estão além do alcance empírico. Pode apontar o norte da Palavra de Deus ${ }^{12}$ quanto a valores metafísicos como é o caso da justiça. Numa tentativa de articular a teologia da Reforma no horizonte do pensamento moderno foi proposto que a perspectiva luterana das duas espécies de justiça contribui para isso na medida em que nos confronta com antigas e ainda impactantes realidades, dentre elas: (1) o fato de que a verdadeira justiça vem de fora, por isso não é inerente aos humanos pecadores; (2) vem de Deus, por meio de Cristo, Aquele que é justo e por isso é a fonte da própria justiça; (3) quando essa justiça é infundida, ela justifica pela fé o pecador que a aceita; (4) torna esse pecador justo em Cristo na medida em que o regenera em justiça; e (5) condiciona-o a produzir frutos de justiça.

Tal reflexão, portanto: (6) nos ajuda a perceber os tipos de justiça em conflito e a discernir a genuína forma de justiça; (7) desmascara as formas enganosas de justiça usualmente disfarçadas na sutileza de pessoas "justiceiras" e "justificáveis"; e (8) interpela de maneira geral a todos os seres humanos e de maneira especial aos cristãos a serem pessoas justas, reproduzindo frutos de justiça nos âmbitos pessoal e comunitário de sua existência. Em seu sentido mais profundo da busca pela justiça, esse projeto se mostra "capaz de conectar-se com

\footnotetext{
${ }^{12}$ Lutero (2005b, p. 383) propõe que "nossa vigilância serve para que o pecado cesse e a justiça apareça e seja preservada, para que reinem a fé e o amor e a descrença seja eliminada. Para tal é necessário promover e lidar sempre e por toda a parte com a Palavra de Deus, tentando, sincera e avidamente, agarrá-la, ouvindo-a de bom grado, cantando-a, pronunciando-a e lendo-a".
} 
pessoas que, em todas as ideologias religiosas ou não-religiosas, pensam e sentem” (BARTH, 2007, p. 134).

Além disso, essa perspectiva nos responsabiliza pela justiça ao se opor à nossa costumeira postura de meros expectadores das crises de nosso tempo. Nos provoca a refletir sobre "aquilo que é obra de Deus e o que cabe à igreja realizar" (GRAFF; PAULY, 2017, p. 350). Nos lembra que a fé tem uma força moldadora da cidadania solidária na medida em que sua vocação profética irrenunciável se projeta no âmbito do interesse coletivo, sendo vista na forma de uma teologia pública que traz a erudição da academia, forjando-a na vivência do púlpito, ao encontro e em resposta às necessidades da vivência em sociedade (BEDFORDSTROHM, 2014, p. 84). Entretanto, ao mesmo tempo, esse projeto nos recorda que, em nossos melhores esforços humanos na busca e luta por justiça, somos nós mesmos necessitados dela e o máximo que podemos chegar é ser proativos mediadores de sua realização. Sendo Deus sua única fonte, somos então provocados a voltar-nos primeiro a ele, a fim de aceitar, entender e amar a justiça e assim poder contrapor-nos às muitas formas de injustiça que assolam a criação, incluindo a irmandade humana.

Somos assim conscientizados de que "o amor da justiça, porém, é graça de Deus" (LUTERO, 2004, p. 368). E que, "por isso, deve-se primeiro tratar de amar a justiça; só então poder-se-ia detestar o pecado por amor da justiça” (LUTERO, 2004, p. 368). Desta forma, em meio aos desafios que nos são contemporâneos, somos chamados a vivenciar tal justiça, desempenhando nossos papéis comunitários com humildade, honestidade e serviço abnegado, em amor pela Justiça. Ou seja, "o homem é chamado a administrar a justiça de Deus que deve permear todas as dimensões da sua existência” (SANTOS, 2010, p. 31). Dessa forma "profética", a justiça cristã solidária atende ao seu dever de protestar em meio ao caos da injustiça contemporânea, contribuindo para reascender na humanidade a chama justiça por meio da fé e da esperança. E assim somos permanentemente lembrados de que, “o que se faz necessário - em meio às incertezas e à falta de clareza - é reconhecer que existe um abrigo que se funda no 
transcendente" (BARTH, 2007, p. 139). Nesse contexto, a perspectiva luterana das duas espécies de justiça se afigura uma interessante opção do pensar teologicamente a justiça em tempos sombrios.

\section{REFERÊNCIAS}

BARBOSA, Luciane Muniz Ribeiro. Estado e educação em Martinho Lutero: a origem do direito à educação. Cadernos de Pesquisa, São Paulo, v. 41, n. 144, p. 866-885, dez. 2011. Disponível em: http://www.scielo.br/scielo.php?script=sci_arttext\&pid=So10o$15742011000300012 \& \operatorname{lng}=$ en\&nrm=iso. Acesso em: 13 maio 2019. http://dx.doi.org/10.1590/So100-15742011000300012.

BARTH, Hans-Martin. A teologia de Martim Lutero num contexto global. Estudos Teológicos, São Leopoldo, v. 47, n. 2, p. 123-144, 2007.

BEDFORD-STROHM, Heinrich. Teologia pública e responsabilidade política. Estudos Teológicos, São Leopoldo, v. 54, n. 1, p. 84-98, jan.-jun. 2014.

EATON, David H. The Economists of the Reformation: An Overview of Reformation Teaching Concerning Work, Wealth, and Interest. SAGE Open, p. 1-9, July-Sept. 2013. DOI: $10.1177 / 2158244013494864$.

GRAFF, Anselmo Ernesto; PAULY, Evaldo Luís. A estrutura teológica missionária bidimensional de Lutero: preleções sobre gênesis e gálatas. Caminhos, Goiânia, v. 15, n. 2, p. 342-353, jul.-dez. 2017. DOI 10.18224/cam.v15i2.5726.

LUTERO, Martinho. A epístola do bem-aventurado apóstolo Paulo aos romanos. In: LUTERO, Martinho. Obras selecionadas. Interpretação bíblica. Princípios. São Leopoldo: Sinodal; Porto Alegre: Concórdia; Canoas: Ulbra, 2003a. v. 8, p. 235-330.

LUTERO, Martinho. Catorze consolações. In: LUTERO, Martinho. Obras selecionadas. O programa da reforma. Escritos de 1520. 2. ed. São Leopoldo: Sinodal; Porto Alegre: Concórdia; Canoas: Ulbra, 2000. v. 2, p. 11-47.

LUTERO, Martinho. Comentário à Epístola aos Gálatas. In: LUTERO, Martinho. Obras selecionadas. Interpretação do Novo Testamento. Gálatas e Tito. São Leopoldo: Sinodal; Porto Alegre: Concórdia; Canoas: Ulbra, 2008. v. 10, p. 15-558.

LUTERO, Martinho. Das boas obras. In: LUTERO, Martinho. Obras selecionadas. O programa da reforma. Escritos de 1520. 2. ed. São Leopoldo: Sinodal; Porto Alegre: Concórdia; Canoas: Ulbra, 2000. v. 2, p. 97-170. 
LUTERO, Martinho. Debate acerca da justificação. In: LUTERO, Martinho. Obras selecionadas. Debates e controvérsias I. 2. ed. São Leopoldo: Sinodal; Porto Alegre: Concórdia; Canoas: Ulbra, 2007b. v. 3, p. 201-239.

LUTERO, Martinho. O capítulo 15 [da primeira carta] de S. Paulo aos Coríntios. In: LUTERO, Martinho. Obras selecionadas. Interpretação do Novo Testamento - Mateus 5-7, 1 Coríntios 15, 1 Timóteo. São Leopoldo: Sinodal; Porto Alegre: Concórdia; Canoas: Ulbra, 2005b. v. 9, p. 281-424.

LUTERO, Martinho. Os capítulos 14 e 15 de S. João, pregados e interpretados pelo Dr. Martinho Lutero e capítulo 16 de S. João, pregado e explicado. In: LUTERO, Martinho. Obras selecionadas. Interpretação do Novo Testamento - João 14-16, 1 João. São Leopoldo: Sinodal; Porto Alegre: Concórdia; Canoas: Ulbra, 2010a. v. 11, p. 15-440.

LUTERO, Martinho. Os sete salmos de penitência. In: LUTERO, Martinho. Obras selecionadas. Interpretação Bíblica. Princípios. São Leopoldo: Sinodal; Porto Alegre: Concórdia; Canoas: Ulbra, 2003b. v. 8, p. 493-548.

LUTERO, Martinho. Prédicas semanais sobre Mateus 5-7. In: LUTERO, Martinho. Obras selecionadas. Interpretação do Novo Testamento - Mateus 5-7, 1 Coríntios 15, 1 Timóteo. São Leopoldo: Sinodal; Porto Alegre: Concórdia; Canoas: Ulbra, 2005a. v. 9, p. 15-280.

LUTERO, Martinho. Preleção sobre a primeira Epístola de João. In: LUTERO, Martinho. Obras selecionadas. Interpretação do Novo Testamento - João 14-16, 1 João. São Leopoldo: Sinodal; Porto Alegre: Concórdia; Canoas: Ulbra, 2010b. v. 11, p. 441-547.

LUTERO, Martinho. Refutação ao parecer de Látomo. In: LUTERO, Martinho. Obras selecionadas. Debates e controvérsias I. 2. ed. São Leopoldo: Sinodal; Porto Alegre: Concórdia; Canoas: Ulbra, 2007a. v. 3, p. 96-191.

LUTERO, Martinho. Sermão sobre as duas espécies de justiça. In: LUTERO, Martinho. Obras selecionadas. Os Primórdios. Escritos de 1517 a 1519. 2. ed. São Leopoldo: Sinodal; Porto Alegre: Concórdia; Canoas: Ulbra, 2004. v. 1, p. 241-248.

PAULY, Evaldo Luís. As possibilidades de uma ética cidadã a partir do mundo do trabalho: as fundamentações absolutas da liberdade em Lutero e Kant. Estudos Teológicos, São Leopoldo, v. 40, n. 2, p. 61-73, 2000.

PROVINCIATTO, Luís Gabriel; KIRCHNER, Renato. O caráter científico da Teologia a partir da conferência Fenomenologia e Teologia de Martin Heidegger. Estudos de Religião, São Bernardo do Campo, v. 31, n. 2, p. 127-151, maio-ago. 2017.

RIETH, Ricardo W. Economia e idolatria: dois temas relacionados da tradição cristã segundo Lutero e teólogos latino-americanos. Estudos Teológicos, São Leopoldo, v. 34, n. 1, p. 72-86, 1994 . 
RIETH, Ricardo W. Fé versus "ganância": uma reflexão sobre o pensamento econômico de Lutero e suas implicações para a Igreja e Teologia no Brasil. Estudos Teológicos, São Leopoldo, v. 33, n. 2, p. 157-167, 1993.

RODRIGUES, Elisa. Lutero, questões hermenêuticas e a reforma protestante. Reflexão, Campinas, v. 41, n. 2, p. 155-163, jul./dez. 2016.

ROSA, Wanderley Pereira da. Teologia política em Martinho Lutero. Horizonte, Belo Horizonte, v. 14, n. 44, p. 1210-1229, out./dez. 2016.

SANTOS, Arthur Francisco Juliatti dos. Justiça: raízes bíblicas e consequências teológicopastorais. Revista de Cultura Teológica, São Paulo, v. 18, n. 69, jan.-mar. 2010.

SUNG, Jung Mo. Lutero, a crítica da idolatria do dinheiro e a dialética do possível.

Estudos de Religião, São Bernardo do Campo, v. 30, n. 2, p. 21-39, maio-ago. 2016.

WACHHOLZ. Wilhelm. Ética no pensamento de Lutero: a serviço da igreja, da economia e da política. Paralellus, Recife, v. 9, n. 20, p. 199-214, jan./abr. 2018.

WACHHOLZ. Wilhelm. O pensamento de Martim Lutero sobre razão e revelação na Igreja, na política e na economia. Horizonte, Belo Horizonte, v. 14, n. 44, p. 1193-1209, out./dez. 2016.

WESTHELLE, Vítor. Cruz, Criação e Teologia: o ponto de encontro entre a teologia da cruz e a teologia da criação em Lutero. Revista de Estudos Teológicos, São Leopoldo, v. 34, n. 3, p. 291-300, 1994.

WITTE JR., John. Luther the Lawyer: The Lutheran Reformation of Law, Politics, and Society. Law and Justice: A Christian Law Review, n. 178, p. 6-36, 2017.

ZWETSCH, Roberto E. Lutero, Justiça Social e Poder Político: aproximações teológicas a partir de alguns de seus escritos. Cadernos teologia pública, São Leopoldo, ano 13, v. 13, n. 113, 2016. 